\title{
Pengaruh Spiritualitas dan HEXACO Personality terhadap Intensi Perilaku Korupsi pada Mahasiswa
}

\section{The Effect of Spirituality and HEXACO Personality toward the Intention of Corruption Behavior on Students}

\author{
Nur Hayati, Fathul Lubabin Nuqul \\ Fakultas Psikologi Universitas Islam Negeri Maulana Malik Ibrahim Malang \\ Email: Nurhayati.aya97@gmail.com; lubabin_nuqul@uin-malang.ac.id
}

KATA KUNCI Spiritualitas, Hexaco Personality, Intensi Perilaku Korupsi.

KEYWORDS Spirituality, Hexaco-Personality, Intention of Corruption Behavior.

ABSTRAK Di Indonesia kasus korupsi dianggap sebagai hal yang biasa dan dimaklumi oleh publik. Kasus korupsi tidak hanya terjadi pada kalangan pejabat akan tetapi sudah menyentuh kalangan akademisi seperti mahasiswa, faktanya dalam praktik keuangan pada salah satu Unit Kegiatan Mahasiswa (UKM) yaitu meninggikan biaya dalam pelaporan pertanggungjawaban dan penyalahgunaan aset lembaga untuk kepentingan pribadi. Berdasarkan fenomena tersebut maka dapat membentuk perilaku kecurangan pada mahasiswa. Adanya kasus korupsi menggambarkan bahwa korupsi mampu mengalahkan keimanan seseorang. Hal ini menunjukkan lemahnya jiwa spiritualitas sebagai benteng keimanan seseorang. Penelitian ini bertujuan untuk mengetahui pengaruh spiritualitas dan HEXACO personality terhadap intensi perilaku korupsi pada mahasiswa. Partisipan dalam penelitian ini adalah 271 mahasiswa. partisipan dipilih menggunakan teknik purposive sampling dengan kriteria terdaftar sebagai anggota organisasi intra kampus atau pernah mengelolah keuangan, atau melakukan pelaporan keuangan atau pernah menggunakan fasilitas organisasi untuk kepentingan pribadi. Data dianalisis dengan menggunakan analisis regresi linier berganda dengan bantuan program SPSS 20 for Windows. Menggunakan metode stepwise dengan tujuan untuk mengetahui variabel bebas yang paling dominan mempengaruhi intensitas perilaku korupsi Hasil penelitian menunjukkan bahwa secara keseluruhan, terdapat pengaruh spiritualitas dan hexaco personality terhadap intensi perilaku korupsi.

ABSTRACT In Indonesia, corruption cases considered as usual and understandable by the public. Cases of corruption do not only occur among officials but have touched academics such as students. The fact is in financial practice in one of the Student Activity Units (UKM), namely raising costs in reporting accountability and misuse of institutional assets for 


\begin{abstract}
personal gain. Based on this phenomenon, it can form cheating behavior in students. The existence of corruption cases illustrates that corruption can defeat one's faith. The fact shows the weakness of spirituality as a stronghold of one's faith. This study aims to determine the effect of spirituality and $h$ HEXACO personality on the intensity of corruption in students. The participants in this study were 271 students. Subjects were chosen using purposive sampling techniques with criteria listed as members of intra-campus organizations or having managed finance, or financial reporting or having used organizational facilities for personal gain. Data is analyzed using multiple linear regression analysis with the help of SPSS 20 for Windows. Using the stepwise method to find out the most dominant independent variables that affect the intensity of corruption behavior The results of the study show that overall, there is an influence of spirituality and hexaco personality on the intensity of corruption behavior.
\end{abstract}

\section{PENDAHULUAN}

Indonesia merupakan sebuah negara yang dapat dikategorikan sebagai negara berkembang. Hal tersebut terlihat dari rendahnya kualitas sumber daya manusia. Sedangkan kualitas sumberdaya manusia tidak terbatas dari segi intelektual akan tetapi menyangkut kualitas moral dan kepribadiannya. Rendahnya tingkat kejujuran dan nilai moral yang dimiliki masyarakat Indonesia dapat menjadi salah satu pemicu terjadinya korupsi (Anisah, 2016).

Di Indonesia kasus korupsi telah mengakar dan menjadi sebuah tantangan dalam pemberantasaanya. Penyebab perilaku korupsi sendiri selain karena perilaku aktif dari pelaku korupsi, adanya strategi mutakhir yang digunakan dan sikap permisif yang semakin berkembang dimasyarakat. Dengan demikian korupsi dianggap sebagai hal yang biasa dan dimaklumi oleh publik (Tim Spora, 2015).

Tindak pidana korupsi berdasarkan profesi atau jabatan dari tahun ketahun mengalami peningkatan. Pada tahun 2015 sebanyak 62 kasus, tahun 2016 menjadi 99 kasus, tahun 2017 menjadi 123 kasus dan pada tahun 2018 sedikit mengalami penurunan menjadi 118 kasus. Sedangkan data Anti Corruption Clearing House
(ACCH) menunjukkan bahwa per 31 Mei 2018 tindak pidana korupsi terdiri dari 76 kasus, penyidikan 85 kasus, penuntutan 50 kasus, inkracht 47 kasus dan eksekusi 48 kasus (Anti Corruption Clearing House, 2018).

Data lain dari Indonesia Corruption Watch (ICW) yang menyoroti korupsi di perguruan tinggi menunjukkan selama 10 tahun sejak 2006 hingga tahun 2016 telah menemukan sebanyak 37 kasus yang terjadi dalam perguruan tinggi. Indonesia Corruption Watch (ICW) telah mencatat sedikitnya 65 pelaku berasal dari sivitas akademika, pihak swasta dan pegawai pemerintah daerah. Lebih spesifiknya terdiri dari 13 orang rektor dan wakil rektor, lima orang dosen dan dua pejabat pemerintahan daerah, 32 orang pegawai dan pejabat dilingkungan fakultas dan 20 orang pihak swasta. Selain itu ditemukan 12 pola korupsi diperguruan tinggi. Dalam hal ini 14 dari 37 kasus penggandaan barang dan jasa menjadi modus yang paling banyak digunakan. Tidak adanya akuntabilitas pada pengelolahan dana kampus dapat memicu terjadinya korupsi (Indonesia Corruption Watch, 2016).

Fenomena yang terjadi menunjukan bahwa kampus sebagai salah satu lembaga pendidikan yang di dalamnya terdapat kaum 
akademisi belum bisa dikatakan sebagai lembaga yang bebas dari kecurangan. Fenomena tersebut juga menggambarkan jika masih banyak ditemukan praktik kecurangan ditingkat perguruan tinggi. Akan menjadi sebuah pertanyaan bagaimana dengan lembaga-lembaga mahasiswa yang berada dibawah nauangan kampus. Hal tersebut menjadi menarik untuk dijadikan sebuah kajian penelitian mengingat dalam praktiknya lembaga mahasiswa juga melakukan laporan pertanggungjawaban dan mendapatkan fasilitas dari kampus.

Sedangkan hasil penelitian yang dilakukan oleh Puspitasari, Haryadi, \& Setiawan (2015) pada Unit Kegiatan Mahasiswa (UKM) menemukan bahwa dalam praktik pengelolahan keuangan pada salah satu Unit Kegiatan Mahasiswa (UKM) dapat dikatakan sesuai dengan fraud definition analysis dalam kategori expense reimbursement schemes yaitu meninggikan biaya dalam melakukan pelaporan pertanggungjawaban keuangan. Selain itu ditemukan adanya penyalahgunaan aset lembaga untuk kepentingan pribadi, misalnya penggunaan aset berupa komputer untuk kepentingan pribadi selain kepentingan Unit Kegiatan Mahasiswa (UKM). Fenomena tersebut sesuai dengan konsep teori yang dijelaskan dalam triangle fraud antara lain pressure yang terjadi pada salah satu UKM yaitu adanya aturan yang mengharuskan

pelaporan pertanggungjawaban $100 \%$, opportunity adanya jabatan yang lebih tinggi serta rasionalisation yaitu adanya sebuah tradisi atau kebiasaan yang dilakukan secara turun temurun dalam pembuatan laporan pertanggungjawaban (Puspitasari, Haryadi, \& Setiawan, 2015). Berdasarkan teori triangle fraud terdapat tiga faktor yang berpengaruh terhadap fraud (kecurangan) adalah kesempatan, motivasi, dan rasionalisasi. Ketiga faktor tersebut memiliki derajat yang sama besar untuk saling mempengaruhi (Tim Spora, 2015).

Pada fase perkembangannya manusia dipengaruhi oleh konteks lingkungan. Tingkah laku individu terbentuk karena adanya hubungan timbal balik antara individu dengan lingkungannya. Teori ekologi memandang bahwa ada tiga system lingkungan yang dapat membentuk ciri-ciri fisik dan mental pada individu yaitu mikrosistem, ekosistem dan makrosistem (Mujahidah, 2015). Fenomena korupsi pada tingkatan mahasiswa dipengaruhi oleh makrosistem. Makrosistem merupakan sebuah system yang terletak pada lapisan terluar dari lingkungan individu. Makrosistem terdiri dari agama, hukum, adat istiadat, budaya, tradisi, pemerintahan, ideologi negara dan lain sebagainya. Komponen tersebut akan memberikan pengaruh pada karakter individu, dalam hal ini lingkungan makrosistem yang akan berpengaruh pada pembentukan karakteristik mahasiswa (Mujahidah, 2015).

Sebagai upaya pemberantasan kasus korupsi di Indonesia. Dibutuhkan peran aktif mahasiswa untuk membentuk budaya anti korupsi dimasyarakat. Fungsi mahasiswa yang pertama adalah sebagai agent of change mahasiswa dapat membantu menyelesaikan berbagai permasalahan yang ada dimasyarakat dengan mengaplikasikan ilmu yang telah dimiliki. Sehingga mahasiswa mampu menjadi motor penggerak untuk melakukan perubahan menuju perbaikan dimasyarakat. Kedua, sebagai social control mahasiswa berperan serta sebagai bagian dari masyarakat tidak hanya sebagai pengamat akan tetapi ikut ambil andil dalam kegiatan masyarakat sehingga mahasiswa dapat menjadi panutan bagi masyarakat. Fungsi yang ketiga adalah sebagai, iron stock sebagai calon generasi penerus bangsa diharapkan dalam hal ini mampu menjadi figure yang berakhlak mulia dalam tugasnya sebagai seorang pemimpin. Tidak kalah penting mahasiswa harus mampu mengaplikasikan budaya anti korupsi dalam kehidupan sehari-hari (Istichomaharani \& Habibah, 2016).

Penjelasan mengenai fungsi mahasiswa tersebut, menggambaran idealnya fungsi mahasiswa di lingkungan masyarakat. Faktanya, ditemukan banyak mahasiswa yang mengatakan antikorupsi 
akan tetapi perilaku dalam kehidupan sehariharinya menunjukkan perilaku korupsi. Begitu juga dengan mahasiswa yang menginginkan transparasi dana faktanya dalam pelaksanaan laporan pertanggungjawaban yang dibuatnya tidak sesuai dengan kegiatan yang dilakukan (Putra, 2018). Wakil Ketua KPK Saut Situmorang mengatakan bahwa korupsi pada mahasiswa banyak terjadi dalam berbagai bentuk antara lain mark-up, gratifikasi pada dosen, penyalahgunaan dana beasiswa, titip absen dan lain sebagainya (Wirawan, 2019).

Korupsi merupakan fenomena yang menarik perhatian publik. Hal tersebut didukung dengan banyaknya hasil penelitian yang menyatakan bahwa adanya dampak negatif dari kasus korupsi. Korupsi juga menyentuh pada pelanggaran moral tidak hanya sebatas kejahatan yang struktural. Korupsi juga telah menciptakan banal korupsi. Banal korupsi diartikan sebagai suatu yang seharusnya tidak wajar menjadi sesuatu yang lumrah dan sudah menjadi prinsip dalam hidup masyarakat sehari-hari (Purwantari, 2010). Memiliki kualitas moral yang baik belum tentu sejalan dengan gelar akademik yang diperoleh setiap individu. Kalangan akademisi tidak dapat diprekdiksi aman atau terhindar dari tindak korupsi (Rastika,2018).

Juru Bicara KPK Johan Budi mengakui, orang-orang yang memiliki latar belakang pendidikan dan berasal dari kalangan pendidikan tinggi yang kemudian mendapatkan jabatan di kursi legislatif ratarata terlibat dalam tindak korupsi (Rastika, 2018). Ditambahkan oleh Masduki (dalam Salama, 2014), bahwa korupsi dapat terjadi pada individu yang memegang kekuasaan atau jabatan yang berkaitan dengan sumber dana dan memiliki kesempatan untuk digunakan sebagai kepentingan pribadi. Faktanya korupsi dilakukan oleh mereka sebagai kaum intelektual dengan cara yang penuh perhitungan dan struktural.

Ruang lingkup korupsi cukup luas termasuk menyangkut aspek perilaku manusia tidak hanya terdiri dari aspek hukum, ekonomi dan politik saja. Di Indonesia korupsi merupakan tindak pidana kriminal yang berbeda pada umumnya. Dengan demikian, kasus korupsi dapat dikategorikan sebagai extraordinary crime (kejahatan luar biasa) dan crimes against humanity (kejahatan tehadap manusia). Oleh karena itu, kasus korupsi perlu diteliti menggunakan pendekatan psikologis (Salama, 2014).

Berdasarkan pendekatan psikologis menurut Ajzen (2005), perilaku manusia dipengaruhi oleh tiga komponen yang membentuk intensitas perilaku kecurangan pada individu. Secara detail ketiga komponen tersebut meliputi attitude toward behavior yang dipengaruhi oleh behavioral belief yang merupakan penilaian positif atau negatif pada suatu perilaku tertentu. Faktor yang kedua adalah normative beliefs yang dipengaruhi oleh subjective norms yang merupakan bagaimana lingkungan individu yang mengharapkan individu berperilaku tertentu. Di dalam subjective norm terdapat beberapa contoh norma yang berlaku dimasyarakat seperti norma agama, sosial, keluarga atau ketika orang-orang yang penting bagi individu atau cenderung dipatuhi oleh individu. Faktor yang terakhir adalah control beliefe yang dipengaruhi oleh perceived behavior control, yaitu sebagai suatu bentuk pengendalian diri pada individu untuk memunculkan suatu perilaku. Hal ini berkaitan dengan kesempatan untuk mewujudkan perilaku tersebut. Misalnya ketika dilingkungan individu tersebut korup maka kecenderungan individu akan melakukan korupsi, begitu juga sebaliknya.

$$
\text { Adanya kasus korupsi }
$$

menggambarkan bahwa korupsi mampu mengalahkan keimanan seseorang. Faktanya banyak tokoh agama yang terjebak dalam kasus korupsi. Hal ini menunjukkan jiwa spiritual sudah tidak mampu menjadi benteng keimanan pada individu. Jalil (2013) mengatakan bahwa individu yang memiliki jiwa spiritual tinggi akan mampu melihat persoalan lebih jernih dan substantif. Spiritualitas dan keimanan seringkali diartikan sama, dikarenakan keduanya 
memiliki arti yang berdampingan. Spiritualitas merupakan pencarian individu untuk memaknai kehidupan dan pengembangan suatu komunitas atau organiasasi. Perilaku yang dimunculkan individu dipengaruhi oleh beberapa faktor salah satunya yaitu spritualitas dan keimanan. Nilai-nilai spiritualitas dan keimanan akan mempengaruhi bagaimana cara individu dalam berpikir dan bersikap (Hage \& Posner, 2013)

Individu yang memiliki kecerdasan spiritual dan keimanan akan berperilaku sesuai dengan keyakinan yang dianut dan diaplikasikan dalam masyarakat. Hal ini menunjukkan bahwa adanya pengaruh dari spiritualitas dan keimanan terhadap perilaku positif (Natalianis \& Darr, 2005). Perilaku positif digambarkan sebagai perilaku yang lebih mempertahankan etika daripada perilaku yang merusak seperti kecurangan. Senada dengan Urumsah, Wicaksono dan Pratama (2016) individu dengan keimanan baik akan memiliki kecenderungan untuk tidak berbuat curang. Hal ini membuktikan bahwa keimanan dan spiritualitas berkontribusi dalam membentuk perilaku beretika (Yilmaz \& Bahcekapili, 2015).

Sama halnya dengan hasil penelitian yang dilakukan Hage dan Posner (2013), kecerdasan spiritual merupakan faktor penting dalam membentuk pemimpinan yang bermoral. Dengan adanya kecerdasan spiritual seorang pemimpin akan mampu membawa organisasi dan anggota organisasi ke jalan yang lebih etis dengan memperkenalkan perilaku-perilaku sesuai dengan norma sehingga dapat menghindari kecurangan.

Hal ini sejalan dengan hasil penelitian yang dilakukan Purnamasari dan Amaliah (2015) bahwa spiritualitas secara efektif mampu meminimalisir terjadinya kecurangan. Spiritualitas pada dasarnya merupakan kemampuan individu dalam membentuk nilai, makna dan keyakinan. Spiritualitas lebih bersifat primer dibandingkan dengan agama atau religiusitas, meskipun bersinggungan tetapi spiritualitas berbada dengan agama.
Spiritualitas memberikan nilai-nilai yang lebih umum sehingga dapat dipahami dan dipegang oleh setiap individu seperti halnya kejujuran dan integritas. Sedangkan agama sebagai jalan pada individu sesuai dengan ajaran yang dianut (Zohar \& Marshall, 2005). Pada penelitian ini mencoba meneliti tentang pengaruh spiritualitas terhadap intensi perilaku korupsi pada mahasiswa.

Di samping spiritualitas, ada faktor lain yang mempengaruhi individu dalam melakukan korupsi salah satunya berawal dari sikap ketidakjujuran. Sikap seperti ini, tentu bukanlah sesuatu yang bersifat otomatis, melainkan telah menjadi karakteristik seseorang. Karakteristik yang ada didalam diri individu dapat dikatakan sebagai trait atau kepribadian. Seiring dengan perkembangan ilmu pengetahuan telah ditemukannyan enam dimensi kepribadian yang disebut dengan $H E X A C O$ personality merupakan struktur kepribadian yang terdiri terdiri dari enam dimensi yaitu Honesty-Humility (kejujuran dan kerendahan hati) (H), Emotionality (emosional) (E), Extraversion (kenyamanan) (X), Agreeableness (keramahan) (A), Conscientiousness (kesadaran) (C), dan Openness to Experience (keterbukaan terhadap pengalaman) (O) (Ashton \& Lee, 2007).

Hasil penelitian menunjukkan bahwa perilaku seseorang di lingkungan organisasi dipengaruhi oleh dimensi kepribadian kejujuran dan rendah hati (Lee, Ashton, \& Vries, 2005). Penelitian tersebut menunjukkan pada dimensi kejujuran berkorelasi negatif terhadap perilaku mencuri, dan pelaporan keuangan. Dimensi ini juga mampu meprediksi tingkat pengawasan terhadap kinerja bawahan disebuah organisasi (Johnshon, Rowatt, \& Petrini, 2011). Sedangkan penelitian yang dilakukan oleh Connelly dan Ones (2008) menunjukkan bahwa individu dengan skor terendah pada dimensi neurotisisme dan memiliki skor tinggi pada dimensi extraversion memiliki kecenderuangan untuk tidak melakukan korupsi. Hemert, Vijver, Poortinga, dan Georgas (2002) 
menemukan bahwa korupsi tidak memiliki korelasi yang signifikan dengan psikotik, extraversion dan neurotisisme. Sama halnya dengan dimensi agreeableness dan opennes to experience tidak adanya korelasi yang cukup signifikan pada individu.

Korupsi memiliki korelasi yang kuat dengan dimensi honesty humility. Prediksi lain mengenai korupsi memiliki hubungan dengan negara-negara yang memiliki kesadaran tinggi akan tetapi memiliki keterbukaan yang rendah terhadap pengalaman akan cenderung lebih memiliki perilaku korup. Kepribadian neurotisisme rata-rata cenderung menjadi prediktor kuat pada kasus korupsi disuatu negara (Connelly \& Ones, 2008). Extraversion berhubungan negatif dengan korupsi, hal ini disebabkan karena individu-individu di negara-negara yang lebih tinggi dalam extraversion kurang patuh sehingga lebih rentan terhadap pelaporan, sebagai contoh korupsi (Hofstede \& McCrae, 2004). Sedangkan dimensi conscientiousness menunjukkan bahwa tidak dapat memprediksi individu memiliki kecenderungan korup.

Secara psikologis, korupsi merupakan perilaku individu yang secara sadar dimunculkan dan dengan sengaja. Perilaku tersebut muncul diakibatkan oleh beberapa komponen. Potensi perilaku merupakan perilaku yang dilakukan secara sadar yang perilaku tersebut belum terwujud secara nyata yang dikenal dengan istilah intensi. Intensi yang dimaksud dalam hal ini adalah intensi individu untuk melakukan perilaku korupsi (Wade \& Travris, 2007).

Dari uraian di atas disimpulkan menjadi hipotesis sebagai berikut; hipotesis mayor bahwa spriritualitas dan kepribadian akan secara simultan mempengaruhi intensi perilaku korupsi. Hipotesis minor pertama spiritual mempunyai hubungan negatif dengan intensi perilaku korupsi. Hipotesis minor kedua bahwa kejujuran (honesty) menjadi faktor kepribadian yang paling kuat pengaruhnya terhadap intensi perilaku korupsi.

Maka dari itu peneliti tertarik untuk meneliti tentang pengaruh spiritualitas dan
HEXACO personality terhadapi intensitas perilaku korupsi pada mahasiswa. Penelitian ini dihadapkan memberi manfaat untuk memetakan faktor penyebab perilaku korupsi, sehingga nantinya akan bisa digunakna sebagai upaya antisipasi keberbahayaan individu akan perilaku korupsi yang aktual.

\section{METODE PENELITIAN Pendekatan}

Penelitian ini menggunakan metode kuantitatif. Pendekatan kuantitatif yang analisisnya menekankan pada data-data numerikal (angka) yang diolah dengan metode statistika (Azwar, 2016). Hasil data yang didapatkan akan dianalisis menggunakan perhitungan statistik regresi linier berganda. Tujuannya untuk mengetahui pengaruh dua buah prediktor $\left(\mathrm{X}_{1}\right.$ dan $\mathrm{X}_{2}$ ) dengan variabel kriterium $(\mathrm{Y})$ (Winarsunu, 2015). Pada penelitian ini terdiri dari dua variabel, yaitu satu variabel terikat (Y), pada penelitian ini adalah intensitas perilaku korupsi dan dua variabel bebas (X) yaitu spiritualitas dan HEXACO personality.

\section{Partisipan}

Adapun partisipan dipilih secara purposif yaitu berdasarkan kriteria yang telah ditentukan peneliti. Pada penelitian ini kriteria partisipan yaitu terdaftar sebagai anggota organisasi intra kampus dan atau pernah mengelolah keuangan, dan atau melakukan pelaporan keuangan dan atau pernah menggunakan fasilitas organisasi. Partisipan yang digunakan dalam penelitian ini sebanyak 271 orang mahasiswa yang terdiri dari 149 perempuan dan 122 laki-laki.

\section{Instrumen}

Guna mendapatkan data dalam penelitian ini dilakukan survey dengan menggunakan tiga skala sebagai berikut:

Skala Intensi Perilaku Korupsi

Skala intensi perilaku korupsi yang dikembangkan oleh peneliti berdasarkan planned behavior theory Feishbein dan 
Ajzen (Ajzen, 2005) yang terdiri 24 aitem dengan koefisien reliabilitas 0,623 dan mencakup tiga aspek yaitu attitude toward behavior, subjective norm, percived behavior control. Planned behavior theory dipilih karena mampu mencirikan potensi perilaku korupsi pada individu.

\section{Spirituality at Work Scale}

Variabel spiritualitas mengadaptasi dengan melakukan forward translation dari spirituality at work (Milliman, Czaplewski, \& Ferguson, 2003). Dalam pengujian dihasilkan nilai koefisien reliabilitas $\alpha=$
0,911 yang terdiri dari 32 aitem yang mencakup tiga aspek yaitu meaningful work, sense of community, dan alignment of values.

The HEXACO -60 a Short Measure

Begitu juga dengan HEXACO personality mengadaptasi dengan melakukan forward translation dari instrumen The HEXACO -60 A Short Measure (Ashton \& Kibeom Lee, 2007) yang terdiri dari 60 aitem yang mencakup enam aspek.

Tabel 1

Dimensi The HEXACO -60 A Short Measure dan Nilai Alpha Cronbach

\begin{tabular}{lll}
\hline No & Dimensi & $\alpha$ \\
\hline 1 & Honesty humility & 0,545 \\
2 & Emotionality & 0,622 \\
3 & Extraversion & 0,585 \\
4 & Agreeableness & 0,576 \\
5 & Conscientiousness & 0,612 \\
6 & Openness to experience & 0,534 \\
\hline
\end{tabular}

Model pemberian skor pada ketiga skala menggunakan jenis Likert.

\section{Teknik Analisis Data}

Data dianalisis dengan menggunakan analisis regresi linier berganda dengan bantuan program SPSS 20 for Windows. Menggunakan metode stepwise dengan tujuan untuk mengetahui variabel bebas yang paling dominan mempengaruhi intensitas perilaku korupsi.

\begin{abstract}
ANALISIS \& HASIL
Hasil penelitian yang dilakukan pada 271 mahasiswa menunjukkan bahwa terdapat pengaruh positif pada variabel spiritualitas dan pengaruh negatif pada variabel honesty humility terhadap intensitas perilaku korupsi pada mahasiswa. Adapun nilai signifikansi terhadap intensitas perilaku korupsi pada mahasiswa ( $\mathrm{F}=20,513 ; p<$ $0,05)$. Artinya spiritualitas dan honesty humility memiliki pengaruh yang signifikan terhadap intensitas perilaku korupsi pada mahasiswa.
\end{abstract}


Tabel 2

Rangkuman Hasil Uji Pengaruh Spritualitas, Honesty Humility, Emotional terhadap Intensitas Perilaku Korupsi dengan Menggunakan Stepwise

\begin{tabular}{|c|c|c|c|c|c|c|}
\hline $\begin{array}{c}\text { Tahap } \\
\text { Stepwise }\end{array}$ & $\begin{array}{c}\text { Variabel Bebas } \\
\text { (Prediktor) }\end{array}$ & Variabel Terikat & $\mathrm{F}$ & $\mathrm{R}^{2}$ & Beta & $\mathrm{t}$ \\
\hline Pertama & $\begin{array}{l}\text { Honesty Humility } \\
\text { Spiritualitas } \\
\text { Emotional }\end{array}$ & $\begin{array}{l}\text { Intensitas } \\
\text { Perilaku Korupsi }\end{array}$ & $15.157 * *$ & 0.146 & $\begin{array}{r}-0.283 \\
0.241 \\
0.113\end{array}$ & $\begin{array}{r}-4.977 * * \\
4.238 * * \\
1.997 *\end{array}$ \\
\hline Kedua & $\begin{array}{l}\text { Honesty Humility } \\
\text { Spiritualitas }\end{array}$ & $\begin{array}{l}\text { Intensitas } \\
\text { Perilaku Korupsi }\end{array}$ & $20.513 * *$ & 0.133 & $\begin{array}{r}-0.289 \\
0.248\end{array}$ & $\begin{array}{r}-5.059 * * \\
4.338 * *\end{array}$ \\
\hline Ketiga & Honesty Humility & $\begin{array}{l}\text { Intensitas } \\
\text { Perilaku Korupsi }\end{array}$ & $20.831 * *$ & 0.072 & -0.268 & $-4.564 * *$ \\
\hline
\end{tabular}

Berdasarkan pada tabel 2 dijelaskan bahwa variabel honesty humility memberikan kontribusi sebesar $\mathrm{R}^{2}=0,072$ atau $7,2 \%$. Sedangkan variabel spiritualitas dan variabel honesty humility terhadap intensitas perilaku korupsi memiliki pengaruh sebesar $\mathrm{R}^{2}=0,133$. Artinya pada variabel spiritualitas dan honesty humility memiliki pengaruh terhadap intensitas perilaku korupsi sebesar 13,3\%. Pada variabel spirtualitas, variabel honesty humility dan emotional memiliki pengaruh sebesar $R^{2}=0,146$. Artinya pada variabel spiritualitas, variabel honesty humility dan variabel emotional memberikan pengaruh terhadap intensitas perilaku korupsi sebesar $14,6 \%$.

Berdasarkan tabel 2 tersebut menunjukkan bahwa variabel honesty humility memberikan kontribusi sebesar $\beta=$ $-0,268$ sedangkan variabel spiritualitas memberikan kontribusi sebesar $\beta=0,248$ dan aspek emotionality tidak memberikan kontribusi $\beta=0,113$. Adapun secara parsial honesty humility $(\mathrm{t}=-4,564 ; \mathrm{p}<0,005)$ dan spiritualitas $(\mathrm{t}=4,338 ; \mathrm{p}<0,005)$ dan emotionality $(\mathrm{t}=1,997 ; \mathrm{p}>0,005)$. Sedangkan pada hipotesis minor yang pertama pada penelitian ini ditolak yaitu tidak terdapat hubungan negatif antara spiritualitas terhadap intensitas perilaku korupsi pada mahasiswa. Pada hipotesis minor yang kedua pada penelitian ini diterima yaitu terdapat pengaruh honesty humility terhadap intensitas perilaku korupsi pada mahasiswa.

\section{DISKUSI}

Hasil penelitian menunjukkan bahwa terdapat pengaruh secara positif antara spiritualitas terhadap intensitas perilaku korupsi pada mahasiswa. Artinya semakin tinggi spiritualitas yang dimiliki mahasiswa maka semakin tinggi pula intensitas perilaku korupsi. Begitu pula sebaliknya semakin rendah tingkat spiritualitas yang dimiliki oleh mahasiswa semakin rendah pula intensitas perilaku korupsi. Hal tersebut mengindikasikan bahwa individu dengan tingkat spiritualitas tinggi tidak menutup kemungkinan untuk melakukan korupsi. Hal ini sama dengan penelitian yang dilakukan oleh Urumsah, Wicaksono dan Pratama (2016) yang menunjukkan adanya pengaruh positif antara kecerdasan spiritual pada individu terhadap niat untuk melakukan kecurangan. Temuan dalam penelitian yang dilakukan oleh Urumsah, Wicaksono dan Pratama (2016) sesuai dengan fenomena yang terjadi di Indonesia. Sebagai contoh pejabat tinggi di Indonesia yang terlibat dalam kasus korupsi dapat kategorikan sebagai individu dengan tingkat kecerdasan spiritual tinggi. Artinya dengan nilai 
spiritualitas yang tinggi tidak menjamin individu untuk berbuat kecurang. Spiritualitas akan membentuk moral pada seorang pemimpin. Akan tetapi pemimpin yang bermoral memiliki potensi untuk memiliki niat melakukan kecurangan (Urumsah,Wicaksono dan Pratama, 2016). Hal ini membuktikan bahwa keimanan dan spiritualitas berkontribusi dalam membentuk perilaku beretika (Yilmaz \& Bahcekapili, 2015).

Korupsi memiliki daya tarik tersendiri pada masing-masing individu. Alasan individu melakukan korupsi adalah ketertarikan tinggi terhadap kekayaan dalam hal ini diartikan sebagai uang. Daya tarik tinggi terhadap uang akan mengakibatkan lunturnya tingkat keimanan dan spiritualitas yang dimiliki individu. Hal tersebut akan memicu munculnya kecurangan atau korupsi. Natalianis dan Darr (2005) menambahkan bahwa adanya pengaruh positif antara spiritualitas dan keimanan seseorang terhadap perilaku beretika daripada perilaku negatif seperti kecurangan. Sama halnya dengan hasil penelitian yang dilakukan Hage dan Posner (2013) bahwa kecerdasan spiritual merupakan faktor penting dalam membentuk pemimpinan yang bermoral bukan sebagai pencegah terjadinya niat dalam berbuat kecurangan.

Sedangkan penelitian yang dilakukan Purnamasari dan Amaliah (2015) menjelaskan spiritualitas mampu meminimalisir terjadinya kecurangan. Pada dasarnya dengan adanya spiritualitas pada individu mampu membentuk makna dan keyakinan. Spritualitas lebih bersifat umum sehingga mudah dipahami oleh setiap individu daripada agama sesuai dengan ajaran yang dianut (Zohar \& Marshall, 2005).

Kecerdasan spiritual yang dimiliki oleh individu hanya mampu membentuk budaya organisasi yang baik. Seperti yang dijelaskan oleh Schein (2004) budaya organisasi merupakan kebiasaan yang dilakukan secara berulang-ulang. Kecerdasaran spiritual akan membawa budaya organisasi yang baik dan mengedepankan nilai moral. Hal ini menunjukkan bahwa organisasi yang baik akan mampu secara efektif mencegah niatan perilaku kecurangan. Martin dan Cullen (2006) menemukan bahwa organisasi yang terbiasa menerapkan perilaku etis atau bermoral akan mencegah terjadinya kecurangan yang dilakukan oleh anggota.

Hal tersebut disebabkan karena adanya perkembangnya pemikiran operasional formal pada usia sebelumnya yaitu pada akhir masa remaja usia 15-20 tahun. Tumbuhnya pemahaman spiritualitas yang lebih baik. Pada usia remaja ditandai dengan adanya pencarian jati diri, eksistensial ditingkatkan menjadi kapasitas pengalaman spiritual dan penentangan terhadap nilai keagamaan. Perkembangan intelektual dan emosi yang banyak mempengaruhi berkembangnya sikap spiritual (Novitasari, Yusuf, \& Ilfiandra, 2017).

Dalam penelitian ini menemukan bahwa, honesty humility lebih mendominasi pengaruhnya terhadap intensitas perilaku korupsi pada mahasiswa. Honesty humility memiliki pengaruh negatif terhadap intensitas perilaku korupsi pada mahasiswa. Artinya semakin rendah tingkat honesty humility yang dimiliki oleh mahasiswa maka semakin tinggi intensitas perilaku korupsi. Begitu pula sebaliknya semakin tinggi tingkat honesty humility pada mahasiswa maka semakin rendah pula intensitas perilaku korupsi yang dimiliki mahasiswa.

Kejujuran dan kerendahan hati sering digunakan sebagai prediktor untuk aspek kepribadian. Kejujuran dan kerendahan hati terbukti berhubungan positif dengan perilaku yang mengarah pada kebaikan. Sedangkan pada perilaku yang tidak diinginkan memiliki hubungan yang negatif. Kejujuran dan kerendahan hati umumnya dikaitkan dengan perilaku prososial, bagaiman individu memperlakukan orang secara adil dan tidak mementingkan kepentingan pribadi. Hasil penelitian menunjukkan bahwa kejujuran dan kerendahan hati secara signifikan berkorelasi negatif dengan agresi dan 
bentuk-bentuk reaksi balas dendam, atau hal-hal yang bersifat terencana. Seperti halnya korupsi yang dilakukan secara terstruktur (Lee \& Ashton, 2012).

Dimensi kejujuran dan kerendahan hati mempengaruhi perilaku individu didalam lingkungan organisasi (Lee, Ashton, \& Vries, 2005). Penelitian tersebut menunjukkan bahwa kejujuran dan kerendahan hati berkorelasi negatif terhadap perilaku kecurangan, seperti mencuri, atau pelaporan keuangan. Selain hal tersebut kejujuran dan kerendahan hati mampu meprediksi tingat pengawasan terhadap kinerja bawahan disebuah organisasi (Johson, Rowatt, \& Petrini, 2011).

Kejujuran berbeda dengan kerendahan hati hasil penelitian menunjukkan bahwa integritas karyawan mencakup kejujuran. Synder dan Lopez (2002) mengemukakan bahwa elemen-elemen kunci dari kerendahan hati termasuk kemampuan untuk mengakui batasan pribadi keterbukaan terhadap saran dari orang lain, menjaga pencapaian, fokus diri yang rendah, dan apresiasi orang lain.

Kerendahan hati implisit (relatif terhadap arogansi) telah meramalkan kinerja akademik (Rowatt, Powers, Targhetta, Comer, Kenndedy, \& Labouff, 2006). Kerendahan hati juga telah terlibat sebagai sumber keunggulan kompetitif terkait dengan kedua pribadi dan kinerja organisasi. Kejujuran dan rendahan hati sebagai dimensi yang luas telah ditemukan berkorelasi terbalik dengan perilaku kontra produktif (Vera \& Lopez, 2004). Sebagai contoh, aspek kejujuran dan kerendahan hati telah berkorelasi negatif dengan psikopati, Machiavellianism, dan quid pro quos seksual (Lee, Ashton, \& Vries, 2005).

Kejujuran dan kerendah hati juga lebih baik meramalkan diri dan materialisme lain yang dilaporkan, pelanggaran etika, dan kriminalitas (semua terbalik) dari dimensi Lima Besar (Ashton \& Lee, 2007). Kejujuran dan kerendahan hati telah meramalkan tingkat kontraproduktif yang sebenarnya lebih rendah perilaku di tempat kerja termasuk kenakalan di tempat kerja
(Lee, Ashton, \& Vries, 2005). Hasil ini telah ditemukan pada orang dari berbagai negara, termasuk Jerman, Kanada, Amerika, dan Belanda (Lee, Ashton, \& Vries, 2005). Karakter kepribadian yang terkait dengan kompetensi sosial dan emosional lebih baik memprediksi kinerja pekerjaan di antara pekerja dalam pengasuhan. Orang-orang jujur dan rendah hati dapat menunjukkan kualitas sosial dan emosional yang diperlukan untuk pengasuhan, seperti empati atau pengampunan.

Menurut Ashton dan Lee (2007) hubungan antara kejujuran rendah hati dan kooperatif versus eksploitasi egois dari yang lain. Jujur rendah hati pada individu telah ditemukan lebih kooperatif dalam ekonomi permainan dari orang yang kurang jujurrendah hati. Orang yang rendah hati juga lebih membantu. Dapat disimpulkan bahwa secara keseluruhan hasil penelitian menunjukkan bahwa mahasiswa yang memilliki honesty humility berpengaruh secara negatif terhadap intensitas perilaku korupsi.

Hasil penelitian ini tidak menemukan hubungan faktor lain seperti extraversion dan neurotisisme, agreeableness dan opennes to experience dalam kaitannya dengan intensi perilaku korupsi (Connelly \& Ones, 2008). Beberapa penelitian lain juga tidak menemukan relasi antara kepribadian dengan intensitas perilaku korupsi Hemert, Vijver, Poortinga, dan Georgas (2002) menemukan bahwa korupsi tidak memiliki korelasi yang signifikan dengan psikotik, pada individu. Sedangkan pada dimensi counscietiousness tidak dapat memprediksi bahwa individu memiliki kecenderungan korup (Connelly \& Ones, 2008).

Korupsi memiliki korelasi yang kuat dengan dimensi honesty humility. Prediksi lain mengenai korupsi memiliki hubungan dengan negara-negara yang memiliki kesadaran tinggi akan tetapi memiliki keterbukaan yang rendah terhadap pengalaman akan cenderung lebih memiliki perilaku korup. Terdapat hubungan positif antara spiritualitas dan intensitas perilaku korupsi. Hal tersebut sejalan dengan 
penelitian yang dilakukan oleh Urumsah, Wicaksono dan Pratama (2016) yang menjelaskan bahwa spiritualitas bukan menjadi faktor yang dapat mempengaruhi intensitas perilaku korupsi pada mahasiswa. Spiritualitas bepengaruh terhadap pembentukan perilaku beretika pada budaya organisasi. Dengan demikian, spiritualitas tidak mampu menurunkan intensitas perilaku korupsi. Sedangkan honesty humility memiliki pengaruh sebesar 7,2\% terhadap intensitas perilaku korupsi. Honesty humility lebih mendominasi daripada dimensi kepribadian yang lainnya. Hal ini disebabkan karena semakin rendah nilai kejujuran yang dimiliki oleh individu maka semakin tinggi intensitas perilaku korupsi yang dimiliki. Menurut Connelly dan Ones (2008) korupsi memiliki korelasi yang kuat dengan dimensi honesty humility.

Puspitasari, Haryadi, \& Setiawan (2015) menunjukkan bahwa perilaku korupsi yang dilakukan mahasiswa terletak pada asset misappropriation dan expense reimbursement schemes yaitu dengan meninggikan biaya dalam pelaporan pertanggungjawaban keuangan. Seperti yang diungkapkan oleh Lee, Ashton, dan Vries (2005) dimensi kejujuran dan kerendahan hati mempengaruhi perilaku individu didalam lingkungan organisai. Penelitian tersebut menunjukkan bahwa kejujuran dan kerendahan hati berkorelasi negatif terhadap perilaku kecurangan, seperti mencuri, atau pelaporan keuangan.

Temuan tersebut menunjukkan bahwa lingkungan akademik dapat dikatakan belum bersih dari tindak korupsi. Hal tersebut perlu mendapatkan perhatian dikarenakan berkaitan dengan output yang diharapkan cenderung tidak sesuai dengan kata lain tidak mencerminkan nilai-nilai dan prinsipprinsip perilaku anti korupsi dalam kegiatan sehari-harinya. Dengan demikian, melalui pendidikan formal perlu adanya peningkatan pembelajaran berperilaku anti korupsi dan fungsi mahasiswa ketika berada dilingkungan masyarakat.

Mahasiswa sendiri sebagai agent of change mahasiswa dapat membantu menyelesaikan berbagai permasalahan yang ada dimasyarakat. Mahasiswa sebagai social control mahasiswa berperan serta sebagai bagian dari masyarakat sehingga mahasiswa dapat menjadi panutan bagi masyarakat. Mahasiswa sebagai iron stock sebagai calon generasi penerus bangsa diharapkan dalam hal ini mampu menjadi figure yang berakhlak mulia dalam tugasnya sebagai seorang pemimpin (Istichomaharani \& Habibah, 2016). Fakta menunjukkan bahwa individu yang berpendidikan tinggi rentan terhadap godaaan korupsi karena didukung dengan menduduki posisi strategis di organisasi kemahasiswaan dengan kucuran data yang besar menggoda mahasiswa untuk melakukan korupsi jika tidak benar-benar ada penanganan dan pencegahan yang baik. Peran perguruan tinggi untuk pemberikan pembelajaran berupa pendidikan anti korupsi pada mahasiswa. Lembaga Kemahasiswaan seperti Dewan mahaswiswa dan unit kegiatan mahasiswa, selain sebagai wadah aktualisasi kegiatan kemahasiswaan juga sebagai role model pada mahasiswa lain. Untuk itu profilling presiden dema atau ketua UKM tidak hanya unggul di prestasi akademik tetapi juga harus mempunyai integritas dan kejujuran diatas rata-rata. Dari organisasi kemahasiswaan itulah perguruan tinggai akan mampu menjadi tonggak pergerakan antikorupsi bagi pembangunan akuntabilitas dan transparansi. Perguruan tinggi berperan sebagai motor penggerak untuk memberhentikan "supply" koruptor di Indonesia.

Penelitian ini masih menyisakan beberapa kelemahan antara lain eksplorasi variabel yang berlokus pada eksternal seperti dukungan sosial pada perilaku korupsi. Selain itu juga menembahkan pada kapabilitas perilaku korupsi, karena mengingat perkembangan perilaku korupsi semakin luas (Wolfe \& Hermanson, 2004). Selain itu varian subjek dan penguatan instrumen juga masih perlu dilakukan untuk menghasilkan kehandalan instrumen penelitian yang lebih baik. 


\section{SIMPULAN}

Spiritualitas dan honesty humility mempunyai pengaruh terhadap intensitas perilaku korupsi mahasiswa. Spiritualitas memiliki pengaruh yang positif terhadap intensitas perilaku korupsi pada mahasiswa. Semakin tinggi tingkat spiritualitas pada mahasiswa semakin tinggi pula intensitas perilaku korupsi pada mahasiswa begitu juga sebaliknya. Artinya spiritualitas tidak selalu menjadi faktor yang mempengaruhi intensitas perilaku korupsi pada mahasiswa. Sedangkan honesty humility semakin rendah tingkat kejujuran pada mahasiswa maka semakin tinggi intensitas perilaku korupsi yang dimunculkan. Artinya kejujuran dan kerendahan hati adalah faktor yang mempengaruhi intensitas perilaku korupsi pada mahasiswa.

\section{DAFTAR PUSTAKA}

Anisah, F. R. (2016). Hubungan antara internal locus of control dengan kecenderungan perilaku korupsi pada karyawan (Skripsi). Universitas Muhammadiyah Malang, Malang, Jawa Timur.

Anti Corruption Clearing House. (2018, Mei). Rekapitulasi Tindak pidana korupsi. Diakses dari https://acch.kpk.go.id/id/statistik/tin dak-pidana-korupsi.

Ashton, M. C., \& Lee, K. (2007). Empirical, theorical, anda practical advantages of the HEXACO model of personality structure. Society for Personality and Social Psychology, 11(4), 150-166.

Ajzen, I. (2005). Attitudes, personality and behavior (2nd edition). Berkshire, UK: Open University Press-McGraw Hill Education.

Azwar, S. (2016). Metode penelitian. Yogyakarta: Pustaka Pelajar.

Connelly, B. S., \& Ones, D. S. (2008). The personality of corruption. CrossCultural Research, 42(4), 353-385.

\section{SARAN}

Secara praktis dari hasil penelitian ini dapat disarankan pada lembaga perguruan tinggi untuk segera dan menguatkan pendidikan anti korupsi di kalangan mahasiswa. Memberikan perhatian tentang integritas figur dari struktural lembaga kemahasiswaan serta memberikan pengawasan pada proses penggunaan anggaran yang diberikan untuk organisasi kemahasiswaan. Secara teoritis, ada banyak konsep tentang nilai misalnya seperti spiritual dan moral masih perlu diujikan kembali dengan variasi subjek yang berbeda. Selain menambahkan pada variabel yang berlokus pada eksternal seperti dukungan sosial. Dibutuhkan pengujikan kembali untuk skala perilaku korupsi sehingga mendapatkan nilai reliabilitas yang lebih baik.

Hage, J., \& Posner, B. Z. (2013). Religion, religiosity, and leadership practices. Leadership \& Organization Development Journal ,36, 396-412.

Hemert, D. A., Vijver, F. J., Poortinga, Y. H., \& Georgas, J. (2002). Structural and functional equivalence of the Eysenck personality questionnaire within and between countries. Personality and Individual Differences, 33(8), 1229-1249.

Indonesia Corruption Watch. (2016, Desember 6). Korupsi di perguruan tinggi. Diakses dari https://antikorupsi.org/id/news/koru psi-di-pergururan-tinggi.

Istichomaharani, I. S., \& Habibah, S. S. (2016). Mewujudkan peran mahasiswa sebagai agent of change, social control, dan iron stock. Prosiding Seminar Nasional dan Call For Paper (hal. 1-6).

Jalil, A. (2013). Spiritual enterpreneurship: Transformasi spiritualitas kewirausahaan. Yogyakarta: LKiS. 
Johnshon, M. K., Rowatt, W. C., \& Petrini, L. (2011). A new trait on the market: Honesty humility as unique predictor of job performance ratings. Personality and Individual Differences, 50, 857-862.

Lee, K., \& Ashton, M. C. (2012). Getting mad and getting even: Agreeableness and honesty-humility as predictors of revenge intentions. Personality and Individual Differences, 52, 596-600.

Lee, K., Ashton, M. C., \& Vries, R. E. (2005). Predicting workplace delinquecy and integrity with the HEXACO and five factor models of personality structure. Human Performance, 18(2), 179-197.

Martin, K. D., \& Cullen, J. B. (2006). Continuities and extensions of ethical climate theory: a metaanalytic. Journal of Business Ethics, 69, 175-194.

Milliman, J., Czaplewski, A. J., \& Ferguson, J. (2003). Work spirituality and employee work attitudes. Journal of Organizational Change Management, 16(4), 426-447.

Mujahidah. (2015). Implemetasi teori ekologi bronfenbrenner dalam membangun pendidikan karakter yang berkualitas. Lentera, 120(2), 171-185.

Novitasari, Y., Yusuf, S., \& Ilfiandra. (2017). Perbandingan tingkat spiritualitas remaja berdasarkan gender dan jurusan. Indonesian Journal of Educational Counseling, 1(2), 163-178.

Natalianis, F., \& Darr, W. (2005). The influence of religiosity and work status on psychological contracts. International Journal of Organizational Analysis, 13(1), 89102.

Purnamasari, P., \& Amaliah, I. (2015). Fraud prevention: relevance to religiosity anda spirituality in the workplace. Social and Behavioral Sciences, 211, 827-835.
Purwantari. (2010, Agustus 30). Jajak pendapat Kompas: Mempertanyakan banalitas korupsi. Diakses dari https://antiikorupsi.org/id/news/jaja k-pendapat-kompasmempertanyakan-banalitas-korupsi.

Puspitasari, Y. R., Haryadi, B., \& Setiawan, A. R. (2015). Sisi remang pengelolahan keuangan organisasi mahasiswa. Procedia - Social and Behavioral Sciences, 6,133-144.

Putra, A. (2018, November 25). Aktivis mahasiswa dan perilaku. Diakses dari

https://www.kpk.go.id/id/berita/publ ik-bicara/342-aktivis-mahasiswadan-perilaku-korupsi.

Rastika, I. (2018, November 25). Orangorang pintar terjerat korupsi. Diakses dari https://nasional.kompas.com/read/2 013/08/16/0919579/Orangorang.Pintar. Terjerat. Korupsi.

Robbins, S. P., \& Judge, T. A. (2005). Organizational behavior. Amerika Serikat: Prentice Hall.

Rowatt, W. C., Powers, C., Targhetta, V., Comer, J., Kenndedy, S., \& Labouff, J. (2006). Development and initial validation of an implicit measure of humiliti relative to arrogance. The Journal of Positive Psychology, 4, 198-211.

Salama, N. (2014). Motif dan proses psikologis korupsi. Jurnal Psikologi, 41(2), 149-164.

Schein, E. (2004). Organization culture and leadership. San Fransisco: Jossey Bass.

Snyder, C. R., \& Lopez, S. J. (2002). Handbook of positive psychology. New York: Oxford University Press.

Tim Spora. (2015). Kapita selekta dan beban biaya sosial korupsi. Jakarta: Direktorat Pendidikan dan Pelayanan Masyarakat.

Trihendradri. (2013). Langkah-langkah mudah menguasai SPSS 21. Yogyakarta: CV Andi Offset. 
Urumsah, D., Wicaksono, A. P., \& Pratama, A. J. (2016). Melihat jauh ke dalam: Dampak kecerdasan spiritual terhadap niat melakukan kecurangan. Jurnal Akuntansi \& Auditing Indonesia, 20, 47-55.

Vera, D., \& Lopez, A. R. (2004). Humility as a source of competitive advantage. Organizational Dynamics, 33(4), 393-408.

Wade, C., \& Travris, C. (2007). Psikologi. Jakarta: Erlangga.

Winarsunu, T. (2015). Statistika dalam penelitian psikologi dan pendidikan. Malang: UMM Press.

Wirawan, O A. (2019, Agustus). Inilah 8 modus korupsi di kalangan mahasiswa versi KPK. Diakses dari https://beritajatim.com/hukumkriminal/inilah-8-modus-korupsi-dikalangan-mahasiswa-versi-kpk/.
Wolfe, D. T., and Hermanson, D. R (2004). The fraud diamond: Considering the four elements of fraud. CPA Journal, 74, 38-42.

Wulandari, A. P. (2012). Gambaran kejujuran sebagai landasan keutamaan moral mahasiswa yang sudah pernah menggambil mata kuliah character building. Humaniora, 3(2), 566-572.

Yilmaz, O., \& Bahcekapili, H. G. (2015). Without god, everiting is permitted? The reciprocal influence of religious and meta-ethical beliefs. Journal of Experimental Social Psychology, 58, 95-100.

Zohar, D., \& Marshall, I. (2005).

Spiritualitas

capital: Memberdayakan $S Q$ di dunia bisnis. Jakarta: Mizan Pustaka. 